\title{
EFFECTIVENESS OF ZAKAH TARGETING IN ALLEVIATING POVERTY IN INDONESIA
}

\author{
Rahmatina A. Kasri
}

\begin{abstract}
Effectiveness of Zakab Targeting in Alleviating Poverty in Indonesia. Zakah is a unique Islamic institution targeted to eight groups of recipients with the aim to redistribute income, reduce poverty and achieve social welfare. However, the impacts and effectiveness of zakah targeting in reducing poverty is rarely measured. This is the main objective of the study. To achieve $i t$, a survey was conducted to collect primary data from zakah recipients in Greater Jakarta Indonesia. The data were subsequently analysed by using descriptive and poverty index analyses. The main results suggest that the incidence, depth and severity of poverty amongst the recipients have decreased due to the contributions from zakah organizations. There are also indications that zakah has been distributed to the most disadvantaged people such as the uneducated and unemployed. The findings provide empirical evidence regarding positive contribution and effectiveness of zakah targeting in reducing poverty in Indonesia. Some policy implications of the findings are also highlighted to enrich discourses on the role of zakah in alleviating poverty in Muslim societies.
\end{abstract}

Keywords: zakah; poverty alleviation; poverty index.

\begin{abstract}
Abstrak. Efektivitas Penetapan Sasaran Zakat dalam Pengentasan Kemiskinan di Indonesia. Zakat merupakan suatu institusi dalam ekonomi Islam yang unik karena hanya menyasar pada delapan asnafyang bertujuan untuk redistribusi pendapatan, mengurangi kemiskinan, dan mencapai kesejahteraan social. Namun, dampak dan efektivitas penetapan sasaran zakat untuk mengurangi kemiskinan masih jarang dilakukan, hal inilah yang merupakan tujuan utama dalam kajian ini. Untuk mencapai tujuan ini telah dilakukan survei kepada penerima zakat di area Jakarta, Indonesia. Selanjutnya data dianalisis dengan menggunakan analisis deskriptif dan indeks kemiskinan. Hasil kajian menemukan bahwa insiden, kedalaman, dan keparahan kemiskinan antar penerima telah menurun seiring dengan kontribusi yang telah dilakukan oleh organisasi pengelola zakat. Selain itu, terdapat indikasi lain bahwa zakat telah didistribusikan kepada orang yang tidak beruntung seperti orang yang tidak berpendidikan ataupun tidak memiliki pekerjaan. Temuan ini memberikan suatu bukti empiris terkait kontribusi positif dan efektivitas penetapan sasaran zakat dalam pengentasan kemiskinan di Indonesia. Implikasi kebijakan dari temuan ini ialah bagaimana meningkatkan peran zakat dalam pengentasan kemiskinan pada masyarakat muslim.
\end{abstract}

Kata Kunci: zakat; pengentasan kemiskinan; indeks kemiskinan 


\section{Introduction}

Poverty seems to be a widespread problem in contemporary Muslim countries. A study by Islamic Development Bank (IDB), as cited by Obaidullah (2008a), reports that five member countries of IDB (Indonesia, Bangladesh, Pakistan, Nigeria and Egypt) account for over half a billion of the world's poor. Indeed, in Indonesia, which is currently the world's largest Muslim country, the number of poor people stands at 28.5 million or around $11.2 \%$ of the population in 2015 (Badan Pusat Statistik 2015). Furthermore, another study linking poverty with the achievement of Millennium Development Goals (MDGs) suggests that there is a lack of progress in halving extreme poverty in IDB member countries, particularly in Sub-Saharan African (Bello and Suleman 2011).

In Islamic perspective, a promising institution that can be utilized to reduce poverty and achieve social welfare is Zakah institution (Ahmad 1991; Salih 1999; Al Qardawi 2000; Chapra 2000; Sirageldin 2000; Ahmed 2004). Zakah, one of the five pillars of Islam, is a share of the poor on the wealth of the rich. The obligation of zakah is clearly mentioned in the Qur'an, where it is specifically targeted to eight groups of people namely the poor (fuqara), needy (masakin), administrator of zakah funds (amil), converts (muallaf), those in bondage (riqab), those indebted (gharimin), those in the cause of God (fi sabilillah) and the wayfarer in need (ibnu sabiil) (Jehle 1994). Viewed this way, from a development perspective, zakah could also be considered as a specific targeting instrument aimed to reduce poverty. It has a similar purpose with other targeted programs for poverty alleviation, such as unconditional and conditional cash transfers. The main difference perhaps related to the religious nature of zakah institution as well as specific zakah recipients as mandated by the Islamic teaching (Arif, 2006).

The important role and effectiveness of zakah for poverty alleviation is evident during the early history of Islam, particularly during the time of Caliph Umar Abdul Aziz, to the extent that he did not find any needy person to receive zakah proceeds (Salih 1999). However, in contemporary Muslim societies, such evidence is rarely found particularly for relatively large Muslim countries (Kahf 1999). Therefore, zakah institution could be considered ineffective in reducing poverty and achieve social welfare in modern Muslim societies.

In Indonesia, in the early years of Islam, the practice of zakah appeared to be informal and voluntary. In fact, zakah payment was generally left to individual Muslims to manage (Salim 2006). However, during the Dutch colonial period in the 1800 s, it started to become institutionalized. Currently, zakah institutions are regulated by the Indonesian government under the Law No. 23/2011, which replaced the Law No. 38/1999, regarding Zakah Management in Indonesia. Given 
the relatively supportive legal-institutional development, new zakah organizations emerged all over Indonesia. As of 2010, there was one national zakah organization (BAZNAS), 33 provincial zakah organizations (BAZDAs), 240 district/regency level BAZDAs and more than 300 non-government zakah agencies. Most of the non-government organizations are non-profit and corporate zakah agencies (Beik 2010). Therefore, in practice, there are three major types of formal zakah organizations known in Indonesia including government, corporate and non-profit zakah organizations. Their development has also been promising. It is reported that the amount of zakah collection has risen from merely 41 billion rupiahs in 2000 to 253 billion rupiahs in 2010 (BAZNAS 2011). The zakah funds are distributed to the deserving recipients under various programs, such as social, health, education and economic programs (PEBS-FEUI and CID 2009).

With this perspective, the main objective of this study is to provide empirical evidence regarding the impacts and effectiveness of zakah targeting in alleviating poverty in Indonesia. To achieve the objectives, the study collects primary data regarding socio-economic conditions of the households receiving zakah assistance in Greater Jakarta Indonesia. The data were subsequently analysed by using descriptive and poverty index analyses.

To proceeds, the article is structured as follow. Section two reviews literature related to poverty and the role of zakah in reducing poverty, particularly in the context of modern Muslim countries. Section three explains the data and methods used in this study. Section four reports the survey results, discusses the main findings and highlights some relevant policy implications from the findings. The final section concludes the study.

\section{Literature Review}

Poverty is a complex phenomenon. Indeed, its definition and measurement tend to vary and often subject to academic and policy debates (Lister 2004). However, it is well understood that the development of effective poverty eradication policies and the monitoring of their efficacy may not be feasible without a clear concept of poverty that could be measured with consistency across space and time (Sirageldin 2000). Thus, despite of its 'relativity' nature, attempts have been consistently done to conceptualize, define and measure poverty.

Literature generally suggests that there are three major approaches on the definitions of poverty. The first approach sees poverty largely in monetary term. Poverty (well-being) is therefore seen from whether individuals or households have enough resources (income) to meet their material needs and subsequently enjoy a 
decent living above poverty line. Under this approach, poverty is usually measured with specific poverty index such as Poverty Headcount index and Sen index. The second approach goes beyond the monetary measures of poverty and extends the resources to specific type of consumption goods including food, shelter, health care and education. Nutritional poverty, for example, might be measured by examining whether children are stunted or wasted. Finally, a broadest approach argues that poverty and well-being also comes from capability to function in a society. Thus, poverty arises when people lack key capabilities and has inadequate resources to 'exist' in a society. Multidimensional poverty index could be seen as a measure for this poverty approach (Haughton and Khandker 2009).

Table 1: Global Strategies for Poverty Alleviation

\begin{tabular}{|c|c|c|c|}
\hline \multicolumn{2}{|r|}{ 1990s } & \multicolumn{2}{|r|}{ 2000s } \\
\hline "Pillars" & Associated Policies & "Pillars" & Associated Policies \\
\hline $\begin{array}{l}\text { Labor } \\
\text { intensity }\end{array}$ & $\begin{array}{l}\text { Small-scale industry; } \\
\text { special employment } \\
\text { measures; promotion } \\
\text { of green revolution in } \\
\text { small-farm agriculture }\end{array}$ & Opportunity & $\begin{array}{l}\text { Microfinance; land- } \\
\text { reform and other asset } \\
\text { redistribution policies; } \\
\text { fiscal and other measures } \\
\text { to reduce inequality; 'pro- } \\
\text { poor' public expenditure } \\
\text { patters }\end{array}$ \\
\hline $\begin{array}{l}\text { Investment } \\
\text { in the human } \\
\text { capital of the } \\
\text { poor }\end{array}$ & $\begin{array}{l}\text { Promotion of primary } \\
\text { health and education, } \\
\text { especially among females; } \\
\text { microfinance }\end{array}$ & Security & $\begin{array}{l}\text { "Tailor-made" social } \\
\text { protection measures; } \\
\text { measures to support asset } \\
\text { diversification; insurance; } \\
\text { 'international public } \\
\text { good" defences against } \\
\text { economic crisis - e.g. } \\
\text { financial regulation; conflict } \\
\text { prevention }\end{array}$ \\
\hline $\begin{array}{l}\text { Social safety } \\
\text { nets }\end{array}$ & $\begin{array}{l}\text { Food subsidies; Social } \\
\text { funds }\end{array}$ & Empowerment & $\begin{array}{l}\text { Democratization, } \\
\text { decentralization; measures } \\
\text { to build 'social capital' }\end{array}$ \\
\hline
\end{tabular}

Source: Mosley and Booth (2003)

Despite the differences in the definitions of poverty, the strategies to fight worldwide poverty tend to be similar (see Table 1). In 1990s, strategies such as promotion of labour-intensive growth through economic openness, investment in infrastructure and provision of basic services to poor people in health and education have been advocated as major poverty alleviation strategies (World Bank 2001:6). In practice, the initiatives pursued include, among others, special employment 
programs, promotion of primary health and educations especially among females, microfinance, social funds and food subsidy. However, the development experience showed that these strategies have many weaknesses (Iqbal 2002). Therefore, "new strategies" for attacking poverty are proposed. The new strategies suggest three ways to alleviate poverty including promoting opportunities, facilitating empowerment and enhancing securities. It was also suggested that specially 'tailored' and 'narrowlytargeted" policies, such as the microfinance policies in Bangladesh, be designed to reduce poverty, vulnerability and inequality in society (Booth and Mosley 2003). More recently, poverty reduction strategies have somewhat shifted to inequality reduction strategies through global-local approach such as targeted communitybased empowerment programs (Rist, Martin et al. 2015).

Most of Muslim countries, particularly prior to 2010, also follow this 'mainstream' perspective in their poverty reduction strategies. This is clearly reflected in numerous poverty studies as well as poverty reduction policy papers in the Muslim societies, including in Indonesia (See, among others, Salih 1999; Ahmed 2004; Bello and Suleman 2011). Zakah institution, unfortunately, has yet become a major part of the poverty reduction strategies in the countries. However, some of the countries such as Pakistan and Malaysia have somewhat integrated the institution into their fiscal system with different results towards poverty reductions (Hasan 1987; Imtiazi 2002; Khan 2007). In this respect, some studies have attempted to measure the distributional impacts of zakah in Muslim countries (see, for example, Jehle 1994 and Toor and Nasr 2003) and therefore provide some ideas to measure impacts and effectiveness of zakah targeting in Muslim countries.

A study by Jehle (1994) constructed income distributions with and without contribution of zakah assistance and subsequently estimated the Atkinson-Kolm-Sen index of income poverty/inequality to analyze the impact of zakah on income inequality in Pakistan. It is found that zakah managed to reduce the measured income inequality in Pakistan during 1987-1988 periods. Using a relatively the same quantitative approach, Toor and Nasar (2003) found positive impact of zakah on the household income in 2001. Despite that, the study also uncovered that some of the recipients may always need income supplemented transfer from zakah institution and other sources. Another study by Arif (2006) examined the effectiveness of zakah targeting in Pakistan and suggested that the public zakah system seems to target the beneficiaries quite well, such that around one million out of seven million poor people in Pakistan received zakah assistance in 2000/2001. Employing descriptive statistics and logistic regression model, the research showed that the more disadvantaged households (i.e. those led by older people, women, uneducated as well as households with poor housing condition and debts) obtained more zakah assistance than the others. 
A more specific and comprehensive study on the impact of zakah distribution on income inequality and welfare loss is conducted by Ibrahim (2006) for the case of Selangor state of Malaysia. The study employs various poverty and inequality measures (such as Lorenz curve, Gini Coefficient, Atkinson index and the FGT indices of poverty) and found that zakah distribution reduces the incidence, extent and severity of poverty. Interestingly, the Atkinson index indicates that the distribution has somewhat increase income inequality in the society. A relatively similar study is conducted by Beik (2010) in Jakarta Province of Indonesia. Investigating the economic impact of zakah for the recipients of two large zakah organizations in the country, the study concludes that zakah has contributed positively in increasing income and decreasing poverty of the household during 2009 period. More recently, some other studies also analyse the relation between zakah and poverty alleviation in selected areas of Indonesia or sometimes compare the case of Indonesia with those of the neighbouring countries (see, for example, Kusuma and Sukmana 2010; Nurzaman 2011; Ali and Hatta 2014). However, the studies did not comment on the effectiveness of zakah targeting in Indonesia.

Overall, the literature suggests that zakah is an appropriate and promising Islamic instrument for reducing poverty and increasing social welfare for Muslim societies. However, particularly in the context of Indonesia, most studies did not emphasize on and/or link the contribution and effectiveness of zakah targeting in achieving the ultimate objective of the institution to create prosperous and justice society. This is the main focus of the current study.

\section{Methods}

In has been mentioned earlier that the study aims to measure the impacts and effectiveness of zakah targeting in Indonesia. To achieve the objectives, a survey was conducted to collect primary data from zakah recipients in Greater Jakarta Indonesia. The information, which includes socio-demographic characteristics and income figures of the zakah recipients, was obtained by using a structured questionnaire as the research instrument. The questionnaire was randomly distributed to around 700 households receiving receiving zakah assistance from seven large zakah organizations in nine regions of Greater Jakarta Indonesia in 2011. In practice, 685 valid responses were received and utilized in the analysis. The multi-stage cluster random sampling is chosen as the sampling method due to its cost-effectiveness and unbiased results, which has made it the most widely used technique for collecting similar data in most poverty studies (Haughton \& Khandker, 2009). In selecting the sample and collecting the relevant data, it was necessary to have the list of zakah beneficiaries in Greater Jakarta Indonesia. The list was obtained from the zakah organizations willing 
to participate in this study. The list suggests that there were around 5605 households receiving zakah assistance in the area in the year 2011. However, and somewhat unfortunate, the list did not classify the recipients according to the targeted eight groups mentioned in the Islamic teaching. Despite that, further analysis could still be conducted. Furthermore, according to Bartlett and Kotrlik (2001), at least 600 samples are needed to achieve 99\% confidence level and 5\% margin error. However, considering the risk or possibility of incomplete questionnaire which might results in missing data situation commonly found for this kind of field survey, more than 700 questionnaires were distributed. Around 685 of them were valid and later used in this study. The zakah organizations include Baznas, BAZIS DKI, DD, RZ, PKPU, BMM and YBM-BRI.

The data obtained were subsequently analysed by using descriptive statistics and poverty index analyses, including decomposition of the poverty index. Descriptive analysis is used to describe characteristics of the respondents and to provide early indications regarding the effectiveness of zakah targeting. Poverty index analysis is utilized to measure changes in the poverty level of the zakah recipients before (without) and after (with) receiving zakah assistance. Meanwhile, decomposition analysis is employed to break down and show changes of the poverty index.

Table 2. Poverty Index

\begin{tabular}{clll}
\hline No & Poverty Index & Formula & \multicolumn{1}{c}{ Main Features } \\
\hline 1 & $\begin{array}{l}\text { The Headcount } \\
\text { Index }\left(\mathrm{P}_{0}\right)\end{array}$ & $P_{0}=\frac{1}{N} \sum_{i=1}^{N} I\left(y_{i}<z\right)$ & $\begin{array}{l}\text { Measure the incidence of poverty; easy to } \\
\text { calculate and interpret. }\end{array}$ \\
$2 \quad \begin{array}{l}\text { The Poverty Gap } \\
\text { Index }\left(\mathrm{P}_{1}\right)\end{array}$ & $P_{1}=\frac{1}{N} \sum_{i=1}^{N} \frac{G_{i}}{z}$ & $\begin{array}{l}\text { Measure the depth of poverty; relatively } \\
\text { easy to measure and interpret; can be used } \\
\text { as a guidance to set the minimum cost of } \\
\text { eliminating poverty (relative to the poverty } \\
\text { line); can be used to compare results of } \\
\text { poverty reduction strategies overtime. }\end{array}$ \\
\hline
\end{tabular}

\begin{tabular}{|c|c|c|}
\hline $\begin{array}{l}\text { The Poverty } \\
\text { Severity Index }\left(\mathrm{P}_{2}\right)\end{array}$ & $P_{2}=\frac{1}{N} \sum_{i=1}^{N}\left(\frac{G_{i}}{z}\right)^{2}$ & $\begin{array}{l}\text { Measure the severity of poverty; gives more } \\
\text { weight to the poor (poorest of the poor) and } \\
\text { provide indication of inequality amongst the } \\
\text { poor; relatively easy to measure but slightly } \\
\text { difficult to interpret; can be used to compare } \\
\text { results of poverty alleviation strategies which } \\
\text { are aiming to reach the poorest overtime. }\end{array}$ \\
\hline
\end{tabular}

Note: $\mathrm{N}$ = where $\mathrm{N}$ is the total number of people in the population (sample), $\mathrm{N}_{\mathrm{p}}$ is the number of poor, $I$ is income function, $y_{i}$ is expenditure, $z$ is the poverty line, $G_{i}$ is Gini index, $G_{p}$ is Gini index for the poor and $\mathrm{g}$ is the economic growth rate.

Source: Haughton and Khandker (2009) 
There are several poverty indices used in this study, namely the Headcount Index $\left(\mathrm{P}_{0}\right)$, the Poverty Gap index $\left(\mathrm{P}_{1}\right)$ and the Poverty Severity Index $\left(\mathrm{P}_{2}\right)$. The indices capture the incidence, depth and severity of poverty (Foster, Greer et al. 1984). These indices are the most commonly used poverty index in policy analysis and have been used by many national statistical agencies as well as academic studies (see, for instance, Ravallion 1994; Ibrahim 2006; Beik 2010). The concepts and nature of each poverty index, including its strengths and weaknesses, is summarized in Table 2.

As for the last method, ideally, the decomposition is done with respect to the eight groups of zakah recipients mentioned in the Qur'an. However, in practice, most zakah organizations in Indonesia distributed zakah proceeds based on the types of programs dedicated to the recipients. This includes, among others, social, health, education and economic programs. Thus, the program classification is used as the main variable to decompose the results of the poverty index analysis. Additionally, since zakah targeting is done by several types of zakah organizations (i.e. government, corporate and non-profit organizations) and implemented in several locations (i.e. nine cities of the Greater Jakarta region), these variables are also utilized in the decomposition analysis. The results are expected to provide more insights into the effectiveness of zakah targeting in Indonesia.

\section{Results and Discussions}

Table 3 summarizes the descriptive statistics regarding the socio-demographic profiles and characteristics of the households receiving zakah assistance in Greater Jakarta in 2011. It is found that most of the households are those led by someone who is relatively young (productive age between 15-45 years), female, married, relatively uneducated (education level up to junior high school) and not working (does not have a fixed job). Further results also revealed that the household size is relatively large (average number of household members are 5.1 persons); typically with two children and two earners (person working to earn income) in the family. Additionally, one household member with disabilities is found for every five households surveyed.

While the findings above are specific to this sample, i.e. the recipients of zakah in Greater Jakarta, the socio-demographic characteristics found are generally consistent with the descriptive profiles of poor households in Indonesia documented by other studies (Alisjahbana and Yusuf 2003; World Bank 2006; Dartanto and Nurkholis 2013). Furthermore, in the context of evaluating the effectiveness of zakah institution as a poverty alleviation instrument, it generally appears that zakah targeting has been relatively successful. 
This is so because the aforementioned groups of people (young, female, marriage, relatively uneducated and not working) could be considered as the most disadvantaged people in the society who are indeed targeted by zakah institution. These type of ashnaf (groups of zakah recipients) are also documented by Arif (2006) in his study about effectiveness of zakah targeting in Pakistan. Nevertheless, unlike the result of this study, Ariff (2006) also noted that female-headed households were relatively better-off than the other groups of zakah recipients in Pakistan due to various supports they received from their extended family.

Table 3: Socio-Demographic Profiles of Respondents

\begin{tabular}{|c|c|c|c|}
\hline \multicolumn{2}{|c|}{ Socio-Demographic Characteristics } & \multirow{2}{*}{$\frac{\text { Frequency }}{433}$} & \multirow{2}{*}{$\frac{\text { Percentage }}{63.21 \%}$} \\
\hline Age & 15 to 45 & & \\
\hline & 46 to 64 & 226 & $32.99 \%$ \\
\hline & 65 to 95 & 26 & $3.80 \%$ \\
\hline & Total & 685 & $100 \%$ \\
\hline \multirow{4}{*}{ Gender } & Male & 186 & $27.15 \%$ \\
\hline & Female & 499 & $72.85 \%$ \\
\hline & Total & 685 & $100 \%$ \\
\hline & Married & 428 & $62.48 \%$ \\
\hline \multirow[t]{2}{*}{ Marital Status } & Single parents & 257 & $37.52 \%$ \\
\hline & Total & 685 & $100 \%$ \\
\hline \multirow{6}{*}{ Education } & Not going to school & 97 & $14.16 \%$ \\
\hline & Elementary School & 199 & $29.05 \%$ \\
\hline & Junior High School & 158 & $23.07 \%$ \\
\hline & Senior High School & 213 & $31.09 \%$ \\
\hline & College/University & 18 & $2.63 \%$ \\
\hline & Total & 685 & $100 \%$ \\
\hline \multirow{6}{*}{ Occupation } & Not working & 328 & $47.88 \%$ \\
\hline & Trader/Small-Businessman & 194 & $28.32 \%$ \\
\hline & Informal Sector Labor & 91 & $13.28 \%$ \\
\hline & Employee & 60 & $8.76 \%$ \\
\hline & Others & 12 & $1.75 \%$ \\
\hline & Total & 685 & $100 \%$ \\
\hline \multirow{6}{*}{ Location } & Jakarta & 377 & $55.04 \%$ \\
\hline & Depok & 77 & $11.24 \%$ \\
\hline & Tangerang & 80 & $11.68 \%$ \\
\hline & Bogor & 83 & $12.12 \%$ \\
\hline & Bekasi & 68 & $9.93 \%$ \\
\hline & Total & 685 & $100 \%$ \\
\hline
\end{tabular}


The survey also uncovered that the households' average monthly incomes before receiving (without) zakah assistance were Rp 1,641,808, meanwhile their incomes after receiving (with) zakah assistance were Rp IDR 1,914,131 (see Table 4). It appears, however, that most of them actually lived with incomes below the average values. This is indicated by the income distribution figures where $50 \%$ of the population ( $\mathrm{p} 50$ ) have monthly mean incomes of only $\mathrm{Rp} 1.3$ million and $\mathrm{Rp}$ 1.5 million respectively under both conditions.

Proceeding to the poverty index analysis, Table 5 summarizes the poverty conditions of the households prior to and after receiving zakah assistance in Greater Jakarta. It is shown that the proportion of poor households prior to receiving zakah assistance was $61.6 \%$. Comparing this figure with the urban household monthly poverty line of $\mathrm{Rp} 1,556,291^{1}$, the proportion of poor households decreased to $53.3 \%$ after receipt of the assistance. This implies a reduction of around $8.32 \%$ in the poverty headcount index amongst the zakah recipients. The study also estimated that the poverty gap index and poverty severity index have been reduced by $4.71 \%$ and $3.34 \%$ respectively by the zakah contributions. Moreover, the nominal poverty gap has also decreased from Rp 393.835 to $\mathrm{Rp} 320.467$ in a monthly basis.

Table 4: Descriptive Statistics of Household Incomes

\begin{tabular}{lcc}
\hline \multicolumn{1}{c}{ Descriptive Statistics } & $\begin{array}{c}\text { Total Income Without Zakab } \\
\text { (In Rupiah) }\end{array}$ & $\begin{array}{c}\text { Total Income With Zakab } \\
\text { (In Rupiah) }\end{array}$ \\
\hline Mean & $100 \%$ & $1,914,131$ \\
St. Deviation & $1,379,289$ & $1,710,637$ \\
Minimum & 0 & 1,000 \\
Maximum & $15,000,000$ & $19,100,000$ \\
\hline Distribution (percentile): & & \\
p5 & 266,667 & 350,000 \\
p25 & 862,000 & 983,333 \\
p50 & $1,300,000$ & $1,500,000$ \\
p75 & $2,010,750$ & $2,315,666$ \\
p95 & $4,025,000$ & $4,763,333$ \\
\hline
\end{tabular}

${ }^{1}$ The figure is calculated by estimating the urban households' poverty line (i.e. multiplying the individual poverty line figures, which were taken from the official statistical data published by Central Statistical Bureau, with the average household size of 5.1as found in this study) and subsequently averaging the figures for the nine regions studied. The standard method was suggested by Ravallion (1994) and used by, among others, Ibrahim (2009) and Beik (2010). 
Overall, the poverty index analysis above suggests that zakah assistances have contributed positively in decreasing the incidence, depth and severity of poverty of the recipients. Therefore, there is strong evidence that zakah institutions have provided positive impacts to reducing poverty in Greater Jakarta Indonesia. These results add to the existing literature on the positive impacts of zakah institutions in alleviating poverty worldwide, which have been found in, among other countries, Pakistan and Malaysia (Jehle 1994; Ibrahim 2006; M Akram and Afzal 2014).

Table 5: Overall Changes in Poverty Index

\begin{tabular}{lcccc}
\hline \multicolumn{1}{c}{ Poverty Index } & $\begin{array}{c}\text { Without } \\
\text { Zakab }\end{array}$ & $\begin{array}{c}\text { With } \\
\text { Zakah }\end{array}$ & Mean Changes (\%) & t-test \\
Headcount Index $(\mathrm{H})$ & 0.616 & 0.533 & $-8.32 \%$ & $7.879^{* * *}$ \\
$\begin{array}{l}\text { Nominal Poverty Gap, in } \\
\text { Rupiah }\end{array}$ & 393,835 & 320,467 & $-73,369$ & $12.059^{* * *}$ \\
$\begin{array}{l}\text { Poverty Gap Index }\left(\mathrm{P}_{1}\right) \\
\text { Poverty Severity Index }\left(\mathrm{P}_{2}\right)\end{array}$ & 0.253 & 0.206 & $-4.71 \%$ & $12.059^{* * *}$ \\
\hline
\end{tabular}

Note: ${ }^{* * *}$ indicates significance levels of $1 \%$.

The analysis also reveals that the poverty headcount index figure above is approximately double those of the poverty gap index and poverty severity index figures. Even though the indices naturally tell different 'stories', these findings indicate that income inequality remains high amongst the households although there has been a relatively large reduction in the proportion of poor people. While inequality is a broad issue that is beyond the scope of this study, it might be appropriate to suggest that policy makers should pay more concerns and implemented better policies to reduce income inequality in Indonesian. This has been noted earlier, albeit in a more general context, by the study of Rist et al. (2015).

Additionally, the nominal value of poverty gap (after receiving zakah assistance) implies that the monthly amount needed to move a poor household above the poverty line is around $\mathrm{Rp} 320,470$. While this amount seems to be relatively 'small', the objective of crossing the poverty line will only be achieved if the assistance has been targeted efficiently and utilized according to the intended purposes. In other words, there should be no 'leakage' in the distribution of zakah proceeds, as has been identified by previous studies such as in the case of Pakistan (Toor and Nasar 2003, Arif 2006).

The next few tables present and discuss the results of the decomposition analysis with respect to the types of zakah organizations, types of zakah assistance 
and location. Table 6 shows that the largest decrease in the headcount index of $11.37 \%$ was found in the households receiving support from the non-profit zakah organizations. Meanwhile, the smallest decrease of $4.74 \%$ was experienced by those associated with the corporate agencies. A similar trend is noted with respect to the poverty gap and the poverty severity indices. Thus, it can be concluded that the proportion, depth and severity of poverty have decreased significantly amongst the households, particularly those affiliated with the non-profit agencies.

Table 6: Decomposition of Poverty Index, by Types of Zakah Organizations

\begin{tabular}{|c|c|c|c|c|c|c|c|c|c|}
\hline \multirow{2}{*}{$\begin{array}{l}\text { Poverty } \\
\text { Index }\end{array}$} & \multicolumn{3}{|c|}{ Without Zakab Assistance } & \multicolumn{3}{|c|}{ With Zakab Assistance } & \multicolumn{3}{|c|}{ Mean Changes } \\
\hline & Government & Corporate & $\begin{array}{l}\text { Non- } \\
\text { Profit }\end{array}$ & Government & Corporate & $\begin{array}{l}\text { Non- } \\
\text { Profit }\end{array}$ & Government & Corporate & $\begin{array}{l}\text { Non- } \\
\text { Profit }\end{array}$ \\
\hline $\mathrm{H}$ & 0.605 & 0.6 & 0.63 & 0.546 & 0.553 & 0.516 & 0.059 & 0.047 & 0.114 \\
\hline Nominal & & & & & & & & & \\
\hline $\begin{array}{c}\mathrm{PG} \text {, in } \\
\mathrm{Rp}\end{array}$ & 383,405 & 408,845 & 390,144 & 315,879 & 369,743 & 295,204 & 67526 & 39102 & 94940 \\
\hline $\mathrm{P}_{1}$ & 0.246 & 0.263 & 0.251 & 0.203 & 0.238 & 0.19 & 0.043 & 0.025 & 0.061 \\
\hline $\mathrm{P}_{2}$ & 0.14 & 0.154 & 0.142 & 0.109 & 0.136 & 0.099 & 0.032 & 0.018 & 0.043 \\
\hline
\end{tabular}

The result above is probably related to capacities and management practices of zakah organizations. Non-profit zakah organizations are non-government agencies specialized in managing zakah collection and distribution. They have the ability to recruit good quality and committed human resources, something that might not be practiced by the government and corporate zakah organizations, as noted by Abdullah (2010) when discussing about zakah management in Brunei Darussalam. The achievement might also be related to the programs implemented by the organizations. Hassan (2010) acknowledged that non-profit organizations usually have better and more comprehensive programs which potentially improve well-being of the recipients and therefore should be the partner of government in fighting poverty, as has been practiced in Bangladesh with considerable success. This is something that could also be adopted in Indonesia.

Table 7 presents the decomposition analysis based on the types of zakah assistance programs. The results indicate that all of the poverty indices appear to be higher amongst the recipients of zakah under social (non-economic) assistance programs in both periods of time. In contrast, those receiving the economic programs seemed to be less poor than the others in all of the indices calculated. Furthermore, the change in the poverty index among the zakah recipient under the economic program was close to $13 \%$, which is the highest figure compared to the 
others. Likewise, the changes in the depth and severity of poverty within this group were also the largest although the values were close to the figures associated with the recipients of health assistance. However, in terms of nominal poverty gap changes, the largest mean change is evident amongst the recipients of education assistance.

Table 7: Decomposition of Poverty Index, by Types of Zakah Assistance

\begin{tabular}{cccccccccccccc}
\hline $\begin{array}{c}\text { Poverty } \\
\text { Index }\end{array}$ & Econ & Edu & Health & Social & Eco & Edu & Health & Social & Econ & Edu & Health & Social \\
\hline H & 0.49 & 0.61 & 0.71 & 0.75 & 0.36 & 0.53 & 0.61 & 0.72 & 0.126 & 0.087 & 0.078 & 0.026 \\
$\begin{array}{c}\text { Nominal } \\
\text { PG, in } \\
\text { Rp }\end{array}$ & 272,840 & 372,388 & 409,639 & 560,861 & 188,395 & 291,637 & 330,420 & 518,856 & 84,445 & 80,752 & 84,578 & 42,005 \\
$P_{1}$ & 0.18 & 0.24 & 0.27 & 0.36 & 0.12 & 0.19 & 0.22 & 0.33 & 0.054 & 0.052 & 0.054 & 0.027 \\
$P_{2}$ & 0.09 & 0.14 & 0.14 & 0.23 & 0.06 & 0.1 & 0.11 & 0.2 & 0.031 & 0.041 & 0.03 & 0.024 \\
\hline
\end{tabular}

The findings above generally suggest that the productive economic assistance seems to be the most effective program to reduce poverty of the poor. Therefore, from policy targeting perspective, perhaps more programs and/or allocations should be directed to the recipients of this program. Alternatively, as most of the economic assistance provided by zakah organizations in Indonesia takes the form of capital (money) provision through Islamic microfinance program (Wibisono, Haidir et al. 2010), more varieties in the productive economic programs could also be implemented either by the zakah organizations or in cooperation with other institutions such as government agencies. A relatively similar conclusion is suggested by some earlier studies (Khan 2007; Ahmed 2008; Hassan 2010) to enhance the contributions of zakah institutions in reducing poverty. However, it should also be remembered that the poor have different issues in their life and not all of them are suitable to receive economic assistances.

Table 8: Decomposition of Poverty Index, by Location

\begin{tabular}{|c|c|c|c|c|c|c|c|c|c|c|c|c|c|c|c|}
\hline \multirow{2}{*}{$\begin{array}{l}\text { Poverty } \\
\text { Index }\end{array}$} & \multicolumn{5}{|c|}{ Without Zakab } & \multicolumn{5}{|c|}{ With Zakab } & \multicolumn{5}{|c|}{ Changes } \\
\hline & Jkt & Dpk & Tgr & Bgr & Bks & Jkt & Dpk & Tgr & Bgr & Bks & Jkt & Dpk & Tgr & Bgr & Bks \\
\hline $\mathrm{H}$ & 0.64 & 0.48 & 0.56 & 0.87 & 0.59 & 0.57 & 0.44 & 0.50 & 0.72 & 0.40 & $-7.16 \%$ & $-3.90 \%$ & $-6.25 \%$ & $-14.46 \%$ & $-19.12 \%$ \\
\hline $\begin{array}{l}\text { Nominal } \\
\text { PG, in } \\
\text { Rp }\end{array}$ & 402,493 & 333,321 & 386,595 & 648,975 & 390,027 & 421,332 & 252,213 & 296,782 & 522,298 & 265,381 & $4.68 \%$ & $-24.33 \%$ & $-23.23 \%$ & $-19.52 \%$ & $-31.96 \%$ \\
\hline $\mathrm{P}_{1}$ & 0.25 & 0.21 & 0.24 & 0.41 & 0.25 & 0.22 & 0.16 & 0.19 & 0.33 & 0.17 & $-3.44 \%$ & $-5.12 \%$ & $-5.67 \%$ & $-8.00 \%$ & $-7.87 \%$ \\
\hline $\mathrm{P}_{2}$ & 0.14 & 0.13 & 0.13 & 0.25 & 0.14 & 0.12 & 0.08 & 0.09 & 0.19 & 0.10 & $-2.39 \%$ & $-4.32 \%$ & $-4.24 \%$ & $-6.16 \%$ & $-4.21 \%$ \\
\hline
\end{tabular}


Another interesting decomposition which might give some insights for policy makers is reported in Table 8. The statistical estimations suggest that two cities enjoying the highest increase in well-being are Bogor and Bekasi cities, two major 'satellite' cities of Jakarta. The proportions of poor households after getting zakah assistance in the cities decrease by $19.21 \%$ and $14.46 \%$ respectively. Similarly, the other measures of poverty changes show the largest decrease for the beneficiaries from Bogor area. In contrast, the smallest change in welfare is more prevalent amongst the households located in Jakarta and Depok cities. Nevertheless, the households in Bogor city are still considered as the poorest amongst the others as indicated by the highest figures of the FGT poverty indices and time to exit poverty measure even after obtaining the assistance. The results clearly points out that, in addition to continuing the existing poverty alleviation program in the city of Bogor, the government should consider partnerships with zakah organizations in attempts to reduce poverty in the area. Similar recommendation has been made earlier by numerous studies (see, among others, Khan 2007; Muhtada 2007; Ahmed 2008; Hassan 2010).

Overall, the findings and analysis of the study conclude that zakah institutions have contributed positively in reducing poverty of the recipients, particularly those receiving zakah assistance in Greater Jakarta Indonesia. There are also indications that zakah has been distributed effectively to the most disadvantaged people such as the uneducated and unemployed. The non-profit zakah organizations also appear to be the organization that delivered the most effective poverty reduction impacts to the recipients, presumably due to its capacities and programs, and therefore should be considered as the government partner in alleviating poverty in Indonesia.

\section{Conclusion}

The main motivation of this study is to provide empirical evidence regarding the impacts and effectiveness of zakah targeting in reducing poverty in Indonesia. To achieve the objectives, the study conducts a survey and collects primary data regarding the socio-demographic and economic conditions of the poor households receiving zakah assistance in Greater Jakarta Indonesia in the year 2011. In analysing the survey results, the study employs a quantitative approach which utilizes descriptive statistics and poverty index analyses.

The main result suggests that the incidence, depth and severity of poverty amongst the zakah recipients have decreased due to the contributions from zakah organizations. Additionally, there are indications that zakah targeting policies seems to be relatively effective during the period. Most disadvantaged groups of society such as the households led by someone who is relatively uneducated, unemployed and single parents are amongst the beneficiaries prioritized by the organizations. 
The findings provide evidence regarding positive impacts and effectiveness of zakah targeting in reducing poverty in Greater Jakarta Indonesia. It is also notable that the non-profit zakah organizations appear to be the organization that delivered the most effective poverty reduction impacts to the recipients studied.

Based on these findings and analyses, several policy implications and recommendations are highlighted. In the context of enhancing the effectiveness of zakah institutions as a poverty eradication instrument, it is strongly suggested that zakah organizations should increase effectiveness of the zakah targeting and implement more effective poverty-focused programs particularly within the productive economic programs aimed to reduce poverty and income inequality. Collaborative and integrated programs in cooperation with other institutions, particularly between the non-profit and the government zakah agencies, are also recommended. The initiatives are expected to increase the impacts of zakah in reducing poverty and accelerate the achievement of a more prosperous Islamic society in the future.

\section{References}

Abdullah, R. B. (2010). Zakat Management in Brunei Darussalam: A Case Study. Seventh International Conference - The Tawhidi Epistemology: Zakat and Waqf Economy, Bangi Malaysia.

Ahmad, Z. (1991). Islam, Poverty and Income Distribution: A Discussion of the Distinctive Islamic Approach to Eradication of Poverty and Achievement of an Equitable Distribution of Income and Wealth. Leicester, Islamic Foundation.

Ahmed, H. (2004). Role of Zakah and Awqaf in Poverty Alleviation. Jeddah: Islamic Development Bank, Islamic Research and Training Institute.

Ahmed, H. (2008). Zakah, Macroeconomic Policies and Poverty Alleviation: Lessons from Simulations on Bangladesh. Journal of Islamic Economics, Banking and Finance, Vol. 4 (2): 81-105.

Al Qardawi, Y. (2000). Fiqh Al Zakah: A Comparative Study of Zakah, Regulations and Philosophy in the Light of Qur an and Sunnah. Saudi Arabia: King Abdulaziz University.

Ali, I. \& Z. A. Hatta (2014). Zakat as a Poverty Reduction Mechanism Among the Muslim Community: Case Study of Bangladesh, Malaysia, and Indonesia. Asian Social Work and Policy Review. Vol. 8 (1): 59-70.

Alisjahbana, A. \& A. A. Yusuf (2003). Poverty Dynamics in Indonesia: Panel Data Evidence. Working Paper, Padjadjaran University.

Arif, G. (2006). Targeting Efficiency of Poverty Reduction Programs in Pakistan. Manila: Asian Development Bank. 
Atkinson, A. B. (1987). On the measurement of poverty. Econometrica: Journal of the Econometrica. Vol. 55 (4): 749-764.

Badan Pusat Statistik. (2015). Statistik Indonesia 2015. Jakarta: Badan Pusat Statistik.

Bartlett, J. E., et al. (2001). Organizational Research: Determining Appropriate Sample Size in Survey Research. Information Technology, Learning, and Performance Journal, Vol. 19 (1): 43-50.

BAZNAS. (2011). Annual Report of BAZNAS 2011. Jakarta: BAZNAS.

Beik, I.S. (2010). Economic Role of Zakat in Reducing Poverty and Income Inequality in the Province of DKI Jakarta, Indonesia: Case Study of the Government Board of Zakat and Dompet Dhuafa Republika. (Unpublished Dissertation). Kuala Lumpur: International Islamic University of Malaysia.

Beik, I.S. (2010). Peran Zakat Mengentaskan Kemiskinan dan Kesenjangan. Republika (Iqtishodia Journal Section). Jakarta, Republika: 5.

Bello, A. \& A. Suleman (2011). The Challenge of Achieving the Millennium Development Goals in IDB Member Countries in the Post-Crisis World. IsDB Occasional paper, 16 .

Booth, A. \& P. Mosley. (2003). The new poverty strategies: what have they achieved? what have we learned? New York: Palgrave Macmillan.

Chapra, M. (2000). The Future of Economics: An Islamic Perspective. Leicester: Islamic Foundation.

Dartanto, T. \& Nurkholis (2013). The determinants of poverty dynamics in Indonesia: evidence from panel data. Bulletin of Indonesian Economic Studies. Vol. 49 (1): 61-84.

Deaton, A. (1997). The Analysis of Household Surveys: A Macroeconomic Approach to Development Policy. Baltimore: Johns Hopkins University Press.

Foster, J. et al. (1984). A class of decomposable poverty measures. Econometrica: Journal of the Econometric Society. Vol. 52 (3): 761-766.

Hasan, N. (1987). Zakat in Malaysia: Present and Future Status. IIUM Journal of Economics and Management. Vol. 1 (1): 47-75.

Hassan, M. K. (2010). An integrated poverty alleviation model combining zakat, awqaf and micro-finance. Seventh International Conference. The Tawhidi Epistemology, Bangi, Malaysia.

Haughton, J. \& S. R. Khandker. (2009). Handbook on poverty and inequality. Washington: World Bank. 
Ibrahim, P. (2006). Economic Role of Zakat In Reducing Income Inequality And Poverty In Selangor. (Unpublished Dissertation). Kuala Lumpur: University Putra Malaysia.

Imtiazi, I. (2002). Management of Zakah Collection and Disbursement: The Administrative and Managerial Structures in State Organizations: The Pakistan Experience. International Training Seminar on Zakah Management.

Iqbal, M. (2002). Islamic Economic Institutions and the Elimination of Poverty. Leicester: Islamic Foundation.

Jehle, G. (1994). Zakat and inequality: Some Evidence from Pakistan. Review of Income and Wealth. Vol. 40 (2): 205-216.

Kahf, M. (1999). The Performance of The Institution of Zakah in Theory and Practice. International Conference on Islamic Economics towards the 21st Century, Kuala Lumpur, Malaysia.

Kasri, R. (2013). Giving Behaviors in Indonesia: Motives and Marketing Implications for Islamic Charities. Journal of Islamic Marketing. Vol. 4 (3): 6-10.

Khan, M. F. (2007). Integrating Faith-Based Institutions (Zakah and Awqaf) in Poverty Reductions Strategies. Pakistan: Institute of Objective Studies.

Kusuma, D. B. W. \& R. Sukmana. (2010). The Power of Zakah in Poverty Alleviation. The Tawhidi Epistemology: Zakat and Waqf Economy. Bangi Malaysia.

Lister, R. (2004). Poverty: Key Concepts. Cambridge: Polity Press.

Akram, M. et.al. (2014). Dynamic Role of Zakat in Alleviating Poverty: A Case Study of Pakistan. Munich Personal RePES Archive. https://mpra.ub.unimuenchen.de/56013/1/MPRA_paper_56013.pdf. accessed at January 8, 2016.

Morduch, J. (1998). Poverty, economic growth, and average exit time. Economics Letters. Vol. 59 (3): 385-390.

Muhtada (2007). The Role of Zakah Organization in Empowering the Peasantry: A Case Study of the Rumah Zakat Indonesia. Yogyakarta Islamic Finance for Micro and Medium Enterprises, Brunei Darussalam.

Nurzaman, M. S. (2011). Zakat and Human Development: An Empirical Analysis on Poverty Alleviation in Jakarta. International Conference on Islamic Economics. Doha, Qatar.

Obaidullah, M. (2008a). Role of Microfinance in Poverty Alleviation: Lessons from Experiences in Selected IDB Member Countries. Jeddah, Islamic Research and Training Institute, Islamic Development Bank. 
Osberg, L. \& K. Xu (1999). Poverty intensity: How well do Canadian provinces compare? Canadian Public Policy/Analyse de Politiques. Vol. 25 (2): 179195.

PEBS-FEUI and CID, Eds. (2009). Indonesia Zakat and Development Report 2009. Jakarta: PEBS-FEUI and CID.

Ravallion, M. (1994). Measuring social welfare with and without poverty lines. The American Economic Review. Vol. 84 (2): 359-364.

Rist, R. C. et al. (2015). Poverty, Inequality, and Evaluation: Changing Perspectives. Washington: World Bank Publications.

Salih, S. A. (1999). The Challenges of Poverty Alleviation in IDB Member Countries. Jeddah: Islamic Research and Training Institute, Islamic Development Bank.

Salim, A. (2006). The Influential Legacy of Dutch Islamic Policy on the Formation of Zakat (Alms) Law in Modern Indonesia. Pacific Rim Law \& Policy Journal. Vol. 15 (3): 683-702

Sirageldin, I. (2000). Elimination of Poverty: Challenges and Islamic Strategies. Islamic Economic Studies. Vol. 8 (1): 1-16.

Toor, I. \& A. Nasar (2003). Zakat as a Social Safety Net: Exploring the Impact. Social Policy and Development Centre.

Wibisono, Y. et al. (2010). Indonesia Zakat and Development Report 2010. in Nasution, M.E., et.al. (ed). Jakarta: PEBS-FEUI and IMZ.

World Bank (2001). World Development Report 2000/2001: Attacking Poverty. Washington: World Bank.

World Bank. (2006). Making the New Indonesia Work for the Poor. Washington: World Bank.

Zheng, B. (1993). An axiomatic characterization of the Watts poverty index. Economics Letters. Vol. 42 (1): 81-86. 